\title{
DENDROCLIMATOLOGICAL POTENTIAL OF DROUGHT-SENSITIVE TREE STANDS IN SOUTHERN TIBET FOR THE RECONSTRUCTION OF MONSOONAL ACTIVITY
}

by

\author{
Achim Bräuning \\ Institute for Geography, University of Stuttgart, D-70174 Stuttgart, Germany
}

\begin{abstract}
SUMMARY
Southern Tibet is influenced by the Asian summer monsoon which causes $70-80 \%$ of the annual precipitation to fall between June and August, showing a steep gradient from east to west. Teleconnections between the tree-ring chronologies of a sampling network have demonstrated a distinct dendroecological region in the catchment area of the Yarlung Tsangpo river, where tree growth is mainly limited by summer precipitation. Ring width at these sites is strongly correlated to late summer (August to October) precipitation of the year prior to growth, indicating that the trees bear a high potential for the reconstruction of the rainfall variability at the northwestern fringe of the monsoonal regime. Light rings and other wood anatomical features like intra-annual growth bands can be observed in the westernmost stands of Pinus densa$t a$. If these growth bands occur in the earlywood of the tree ring, they can be explained by cold events during spring; if they are located in the transition zone between earlywood and latewood, they are caused by dry conditions during May and especially June, which points to a delayed arrival of the moist monsoonal air masses in southern Tibet in the corresponding years.
\end{abstract}

Key words: Tibetan plateau, monsoon, dendroclimatology, conifers, intra-annual density fluctuations.

\section{INTRODUCTION}

The Tibetan plateau, due to its huge extension, its geographical position in subtropical latitudes rich in solar radiation, and its unique elevation of about $4500 \mathrm{~m}$ above see level on average, represents an enormous heat source that plays a triggering role for the whole Asian monsoon system (Murakami 1987; Domrös \& Peng 1988; Haffner 1997). The moist monsoonal air masses are blocked on their way northward by the Himalayan mountain system and are forced to use the deep gorges of the north-south running rivers of Jinsha Jiang (Yangtze), Lancang Jiang (Mekong) and Nu Jiang (Salween) as pathways to penetrate deeply onto the Tibetan plateau (Chang 1981), bringing the required moisture which allows rich coniferous forests to thrive on the mountain slopes. As a consequence, a steep precipitation gradient from southeast to 
northwest can be observed (Anonymous 1990: 66), with 70-80\% of the annual precipitation falling between June and August. Because of its marginal position, this region is supposed to be very sensitive to fluctuations in the intensity of the summer monsoon.

However, the general climatic conditions during the monsoon season are strongly modified by the topography (Schweinfurth 1981). A great amount of the summer precipitation is of convective character, caused by local circulation systems with a daily periodicity (Flohn 1958, 1987), forcing the unstable moist air masses to ascend and rain out over the mountain crests and slopes. The valley floors themselves lie below the condensation level that can often be seen as a belt of clouds covering the middle parts of the slopes and are characterized by dry conditions (Schweinfurth 1956). The valley of the Yarlung Tsangpo in southern Tibet is an excellent example for this phenomenon: Schweinfurth (1957: $217 \mathrm{f}$.) describes steppe forests composed of Pinus densata and Quercus semecarpifolia thriving in the valley bottom, contrasting sharply to the moist forests of Abies delavayi var. motouensis, Abies georgii var. smithii and Larix griffithiana (Li Bosheng 1993) covering the slopes.

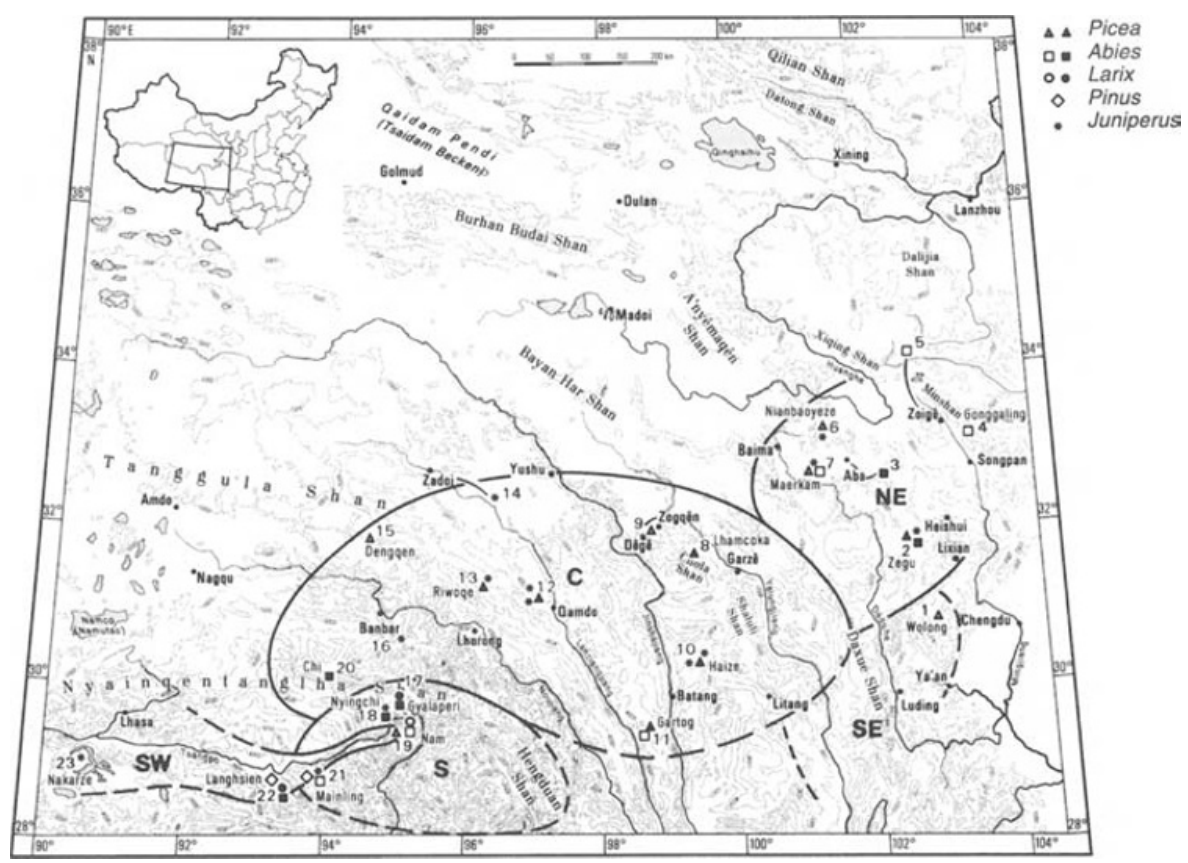

Fig. 1. Location of the tree-ring chronologies developed in eastern Tibet and dendroecological regions derived from cross-dating of chronologies from distant sites. Full symbols mark sites where maximum latewood density as well as total ring width were measured, empty symbols mark sites where only ring width was registered. Map basis: Geographisches Institut, Universität Göttingen, Germany. 
Besides a high variability in ring width, the westernmost stands of Pinus densata near the forest border to the steppe vegetation show intra-annual growth bands or density fluctuations. These wood anatomical features have been described from dry forest ecotones, dry intramontane valleys or at low elevations in different regions (Glock 1955; Fritts 1976; Schweingruber 1980; Villalba \& Veblen 1996). The present study aims to evaluate the potential of drought-sensitive tree-ring sites for an estimation of the variability of the summer monsoon in southern Tibet.

\section{Tree-ring material}

The tree-ring sites treated in this study are part of a sampling network covering the eastern part of the Tibetan plateau. From analyses of the teleconnections between 30 ring-width chronologies from 23 locations and 14 chronologies of maximum latewood density, a division into various dendroecological regions or growth provinces was established (Bräuning 1994, 1999a, b) (Fig. 1). It could be shown that tree growth is primarily controlled by moisture conditions in an area (SW in Fig. 1) covering the bottom of the Tsangpo valley west of Namjabarwa and broadening further to the west. The chronologies from this region (Nos. 19, 21, 22, and 23 in Fig. 1) are characterized in Table 1 . In contrast, tree growth in the other forest regions of eastern Tibet (labelled as S, C, SE and NE in Fig. 1) is mainly limited by temperature conditions.

\section{Meteorological data}

In Table 2, the locations of the meteorological stations in or near the Tsangpo valley are given. The time span of the records is very short; in the case of Mainling,

Table 1. Characterization of tree-ring chronologies from the Yarlung Tsangpo River and surroundings.

\begin{tabular}{|c|c|c|c|c|c|c|}
\hline $\begin{array}{l}\text { Site No. } \\
\text { (Fig. 1) }\end{array}$ & Location & $\begin{array}{l}\text { Eleva- } \\
\text { tion } \\
\text { (m asl) }\end{array}$ & Tree species & $\begin{array}{l}\text { Chronology } \\
\text { name }{ }^{1}\end{array}$ & $\begin{array}{l}\text { No. of } \\
\text { trees }\end{array}$ & Time span \\
\hline 19 & $29^{\circ} 35^{\prime} \mathrm{N} / 95^{\circ} 10^{\prime} \mathrm{E}$ & 3350 & Picea $\mathrm{cf}$. likiangensis & NAM PCLI & 11 & 1844-1989 \\
\hline 21 & $29^{\circ} 02^{\prime} \mathrm{N} / 93^{\circ} 54^{\prime} \mathrm{E}$ & 3430 & Pinus densata & MAIN PIDE* & 15 & $1765-1993$ \\
\hline \multirow[t]{3}{*}{22} & $28^{\circ} 55^{\prime} \mathrm{N} / 93^{\circ} 14^{\prime} \mathrm{E}$ & 3700 & $\begin{array}{l}\text { Abies georgei } \\
\text { var. smithii }\end{array}$ & LANG ABGS* & 13 & $1707-1993$ \\
\hline & $28^{\circ} 55^{\prime} \mathrm{N} / 93^{\circ} 14^{\prime} \mathrm{E}$ & 3700 & Larix griffithiana & LANG LAGR & 8 & $1736-1993$ \\
\hline & $28^{\circ} 59^{\prime} \mathrm{N} / 93^{\circ} 13^{\prime} \mathrm{E}$ & 3500 & Pinus densata & LANG PIDE* & 12 & $1760-1993$ \\
\hline 23 & $28^{\circ} 59^{\prime} \mathrm{N} / 90^{\circ} 28^{\prime} \mathrm{E}$ & 4500 & Juniperus cf. tibetica & NAKA JUTI* & 8 & $1680-1994$ \\
\hline
\end{tabular}

1) The second part of the chronology name refers to a list of abbreviation codes of tree species used by the International Tree-Ring Databank (ITRDB, Grissino-Mayer 1993). In this code, PIDN stands for Pinus densata s.1., including P. tabulaeformis and P. yunnanensis. In the present study, PIDE is used to emphasize that Pinus densata [P. tabulaeformis var. densata (Masters) Rehder] was investigated. For species which are not included in the list mentioned above, the abbreviations marked with an asterisk are suggested. 
Table 2. Name, location and time span of the data series of the meteorological stations.

\begin{tabular}{|lccc|}
\hline Station name & Location & $\begin{array}{c}\text { Elevation } \\
\text { (m asl) }\end{array}$ & Time span \\
\hline Nyingchi & $29^{\circ} 34^{\prime} \mathrm{N} / 94^{\circ} 28^{\prime} \mathrm{E}$ & 3000 & $1951-1984$ \\
Mainling & $29^{\circ} 41^{\prime} \mathrm{N} / 94^{\circ} 06^{\prime} \mathrm{E}$ & 3000 & $1980-1992$ \\
Tsetang & $29^{\circ} 15^{\prime} \mathrm{N} / 91^{\circ} 46^{\prime} \mathrm{E}$ & 3552 & $1957-1992$ \\
Gonggar & $29^{\circ} 18^{\prime} \mathrm{N} / 90^{\circ} 59^{\prime} \mathrm{E}$ & 3555 & $1978-1992$ \\
Lhasa & $29^{\circ} 42^{\prime} \mathrm{N} / 91^{\circ} 08^{\prime} \mathrm{E}$ & 3649 & $1941-1990$ \\
Nakarze & $28^{\circ} 58^{\prime} \mathrm{N} / 90^{\circ} 24^{\prime} \mathrm{E}$ & 4432 & $1962-1991$ \\
\hline
\end{tabular}

which is situated close to the tree stands of site 21 , only 12 years of data are available. The record of Lhasa covers 50 years, but it cannot be used to calibrate growth at the tree sites under consideration with the exception of NAKA JUTI.

In contrast to temperature variations, which are highly uniform within the investigation area, precipitation data show only a low spatial representativeness (Böhner 1994, 1996; Table 3). This is typical for subtropical mountain systems, where meteorological stations are usually located in valley bottoms and do not represent moisture conditions on the slopes (Flohn 1987).

Table 3. Spatial representativeness (in $\mathrm{km}$ ) of temperature and precipitation data from Tibet covering the period 1951-1980 (after Böhmer 1996).

\begin{tabular}{|c|c|c|c|c|c|c|c|c|c|c|}
\hline \multirow[b]{2}{*}{ Station } & \multicolumn{5}{|c|}{ Temperature } & \multicolumn{5}{|c|}{ Precipitation } \\
\hline & W & $\mathrm{Sp}$ & $\mathrm{Su}$ & A & Y & W & $\mathrm{Sp}$ & $\mathrm{Su}$ & A & $\mathrm{Y}$ \\
\hline Nyingchi & 364 & 420 & 473 & 508 & 504 & 209 & 213 & 210 & 193 & 212 \\
\hline Lhasa & 305 & 455 & 455 & 546 & 494 & 242 & 258 & 238 & 239 & 240 \\
\hline
\end{tabular}

$\mathrm{W}=$ winter, $\mathrm{Sp}=$ spring, $\mathrm{Su}=$ summer, $\mathrm{A}=$ autumn, $\mathrm{Y}=$ year.

\section{METHODS}

From each tree, two cores were collected using standard increment borers. Ring width was measured with a precision of $0.01 \mathrm{~mm}$ after preparing the sample surface with a razor blade. Besides ring width, maximum latewood density was measured from the sites LANG LAGR and LANG ABGS, which is of minor importance for the topic of this paper. After cross-dating, the two radii were averaged to a mean curve and the biological age trend was removed applying conservative methods of trend elimination to provide as much low frequency variation in the chronologies as possible (Cook et al. 1995). Index chronologies of ring width were derived by dividing the raw values by the trend curve (Bräker 1981). If a linear function could not be used for trend elimination, an exponential function (Fritts 1976) or a kernal filter of 50 years was applied. 


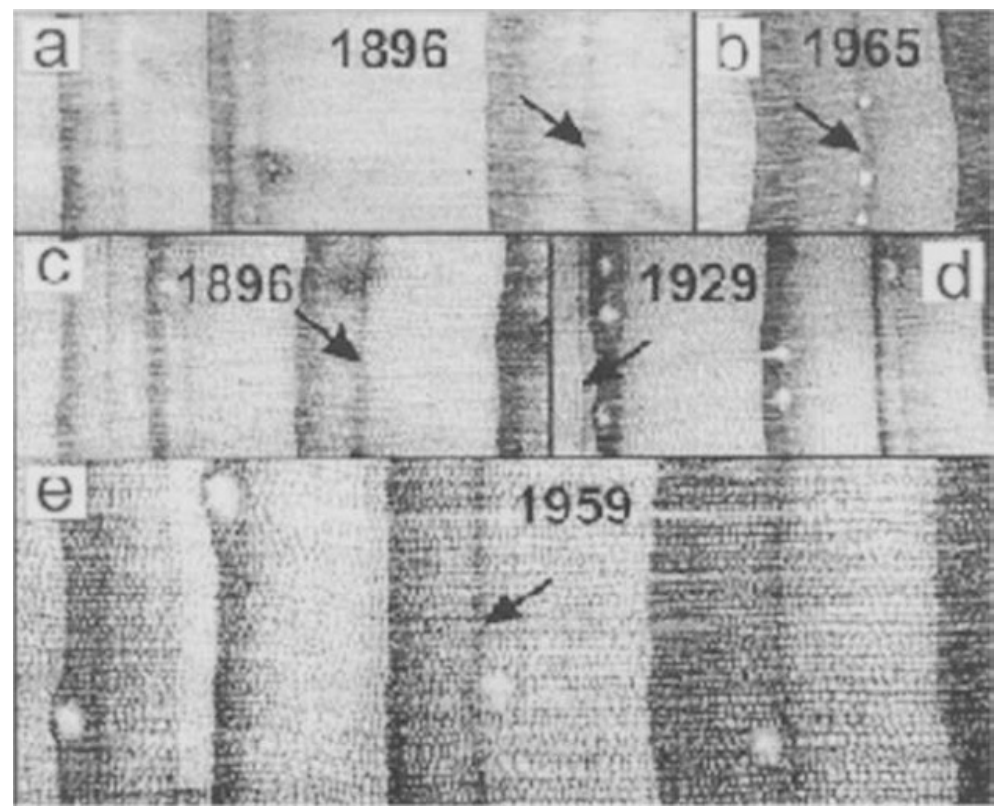

Fig. 2. Examples of wood anatomical features found in Pinus densata at the site Langhsien. Numbers indicate the dating of individual tree rings. For further explanation see the text.

After identification and dating of missing rings and light rings ( $\measuredangle$ in Fig. $2 d$ ), the 24 cores from LANG PIDE were re-examined and intra-annual band structures evaluated and precisely dated. The position of an intra-annual band within the annual ring was classified as occurring completely within the earlywood ( $\backslash$ in Fig. 2a, b), within the latewood, or in the transition zone between earlywood and latewood ( $\measuredangle$ in Fig. 2e). The rate of transition within the intra-annual band from the latewood to the earlywoodtype of cells was distinguished as being abrupt (within less than 2 rows of cells, $\downarrow$ in Fig. 2e), clear (within 2-4 rows of cells, $\backslash$ in Fig. 2c) or gradual (within more than 4 rows of cells, $>$ in Fig. 2a). Each core was treated as a sample of its own, since the amount of intra-annual bands can differ strongly not only between different trees but also between two radii of a single tree. Despite this individual variability, not only single events, but also characteristic series of anatomical anomalies can be identified in different trees, like in the years 1895-1897 (Fig. 2a \& c, see also Fig. 7c), proving their climatic significance.

Because of the shortness of the meteorological records and their low spatial representativeness in regard of moisture conditions, it is not possible to calibrate tree growth and climate data in the way usually done using response functions and other multiple regression techniques, where one-third to one-half of the meteorological record should be used for the verification of the statistical relationships (Bradley \& Jones 1992). Therefore, only simple correlation analyses and signature tests were applied to provide a rough estimate of the causal relationships between tree-ring and climate data. 


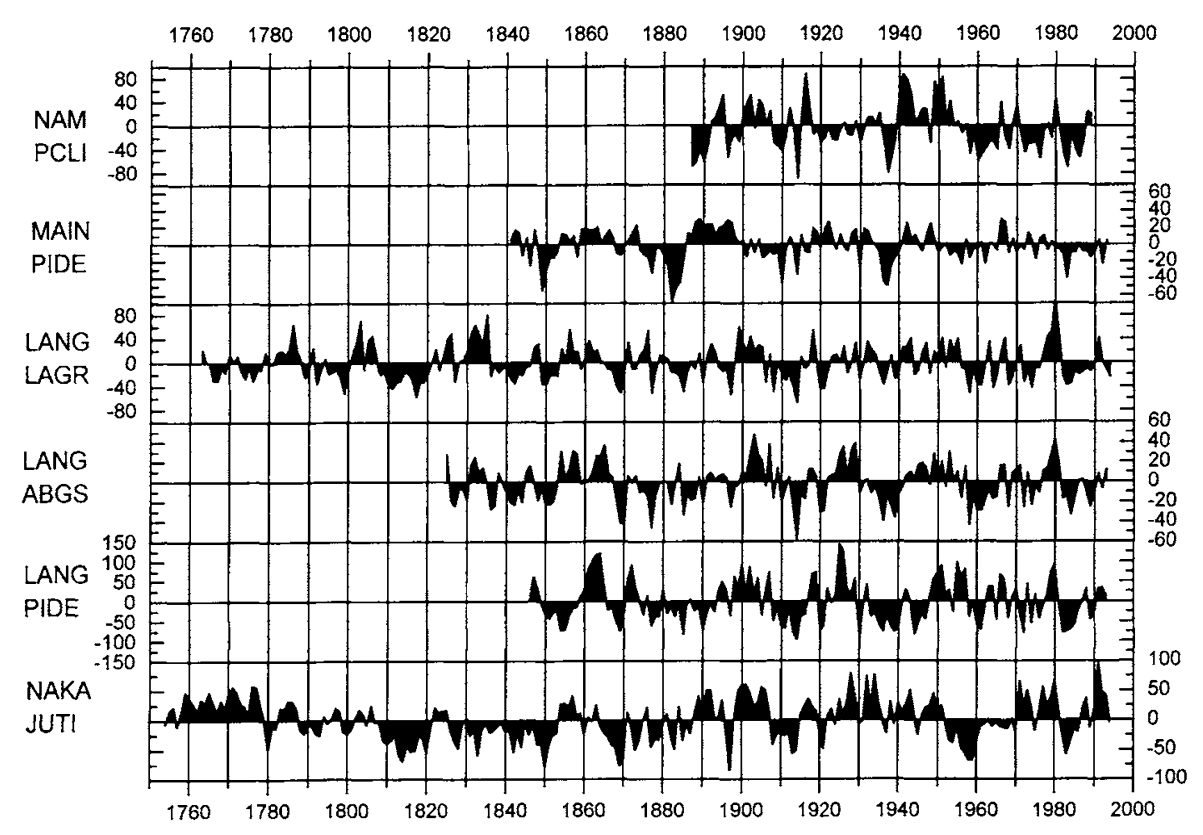

Fig. 3. Ring-width indices from chronologies in or near the Tsangpo valley.

\section{RESULTS}

\section{Tree-ring-climate relationships}

The ring-width series from the Tsangpo valley show strongly coherent growth patterns during the last 200 years (Fig. 3) which is confirmend by high values of crosscorrelation between the chronologies (Bräuning 1999a, b) and points to a strong climatic signal reflected by the tree-ring curves. Individual deviations from the common pattern are the phases of reduced growth from 1882-1886 in the chronology MAIN PIDE and from 1952-1960 in the chronology NAKA JUTI. While the former event reflects the effect of a forest fire (Krauter 1997), the latter was probably caused by site disturbances due to wood-cutting activity. Common periods with generally reduced tree growth occur from 1808-1820, 1836-1843, 1865-1870, 1875-1890, 19081915, 1935-1940, 1958-1965 and 1982-1990.

The correlation functions and the results of the sign test ('Gleichläufigkeit') for the chronology LANG PIDE and the climate data of Tsetang are given in Figure 4. Strong negative correlation values and 'Gleichläufigkeit' exist with the temperatures of $\mathrm{Au}$ gust-October of the year prior to growth, whereas precipitation of the previous summer (June-August) is positively correlated with ring width. The same relationships between ring width and climate occur in August of the growth year. Negative correlations with winter precipitation cannot be explained, since the amount of winter precipitation is negligible. There are no positive correlations between ring width and temperature. These results can be interpreted in the way that moisture conditions are 
the limiting factor for tree growth at this site, with a strong influence of the climatic conditions during the late summer of the previous year.

This can clearly be seen in Figure 5, where the chronology is plotted against the reversed late summer temperatures (August-October) of the year prior to growth.

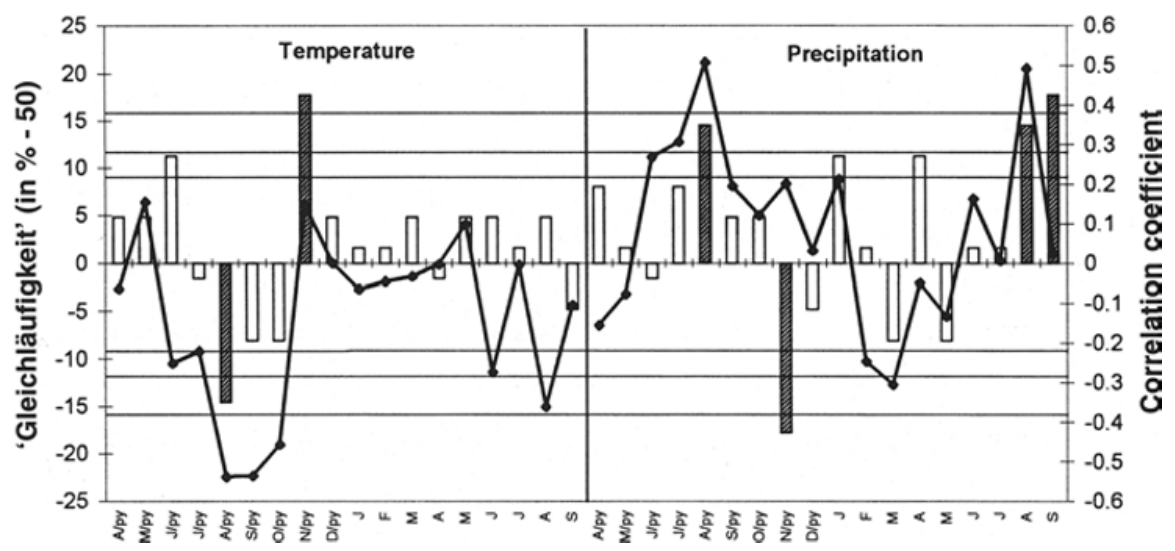

Fig. 4. Correlation function (line) and 'Gleichläufigkeit' (bars, given as deviation from the $50 \%$ random value) between the ring-width chronology LANG PIDE and the climate data from Tsetang (1957-1992) from April of the previous year (A/py) to September of the current year (S). Horizontal lines mark the 90,95 , and $99 \%$ confidence levels for the correlation coefficient, hatched bars show significant 'Gleichläufigkeit' at the $90 \%$ level.

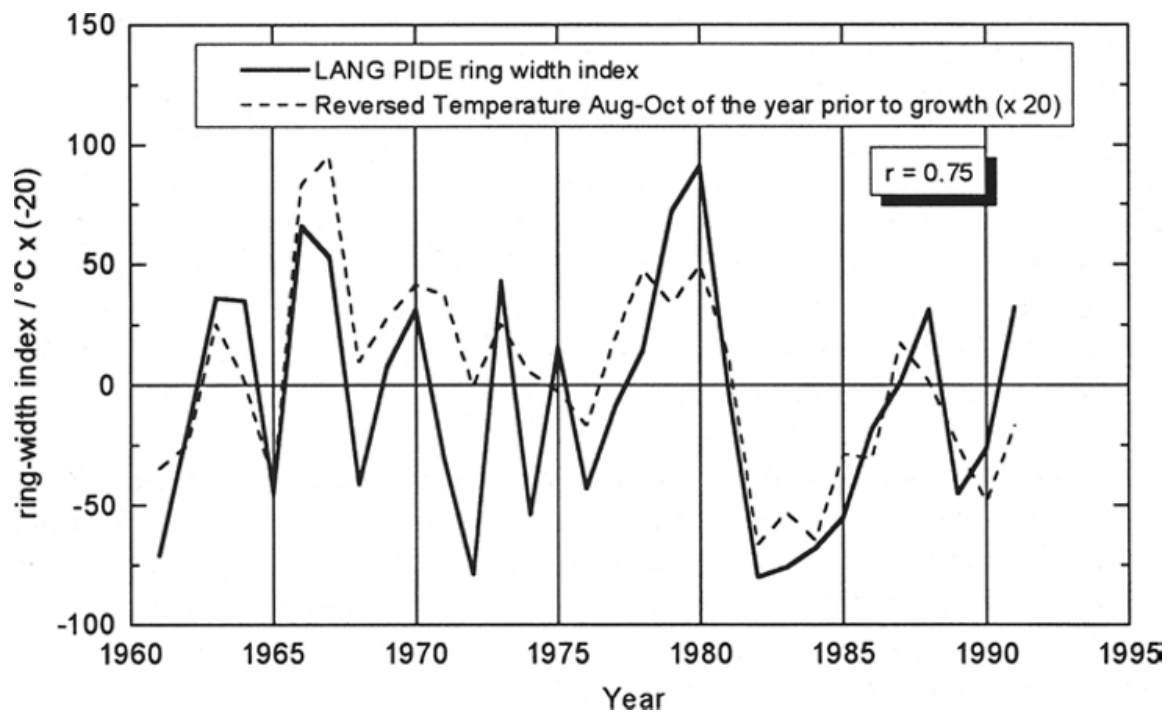

Fig. 5. Comparison between the ring-width index of chronology LANG PIDE and the reversed temperature from August-October of the year prior to growth (scale adjusted to the tree-ring curve). 
The temperature data, which give a rough estimate of the evaporation rate, seem to represent the general moisture conditions better than the monthly values of precipitation, since the latter contain no information about the type and the effectivity of rainfall and the duration of dry periods between single rainfall events. Temperature and precipitation during the summer months are strongly negatively correlated with each other (August: $r=-0.58$, September: $r=-0.67$, October: $r=-0.56$ ), so a warm summer also means a dry summer for the trees. The correlation coefficient of $r=0.75$ explains $56 \%$ of the variance of the tree-ring curve and indicates a strong relationship between ring-width and moisture conditions during the previous late summer. Corresponding relationships between climatic parameters and tree growth can be observed at all the other tree-ring sites in this dendroecological region, which is consistent with the high similarity between the tree-ring series, even if different species are concerned. The results of the correlation functions and the sign tests are summed up in Figure 6.
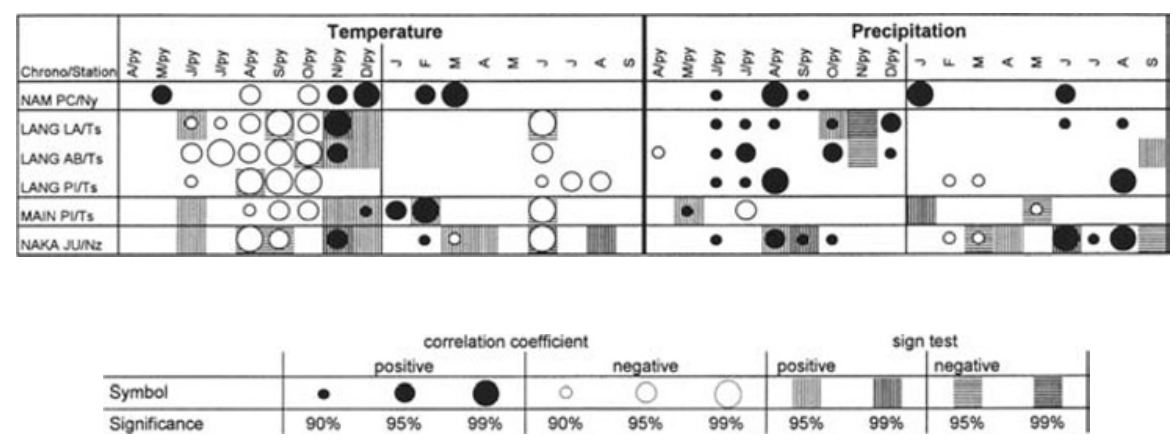

Fig. 6. Correlation functions and sign test between ring-width chronologies from the Tsangpo valley and meteorological data from the nearest meteorological stations from April of the previous year (A/py) to September of the current year (S). Abbreviations for meteorological stations: $\mathrm{Ny}=$ Nyingchi, $\mathrm{Nz}=$ Nakarze, $\mathrm{Ts}=$ Tsetang.

\section{Intra-annual bands and climatic conditions}

Figure 7 summarizes various aspects of the formation of intra-annual bands and other wood anatomical features. In Figure 7a missing rings, 'light rings' [latewood zone with thin-walled tracheids] and single rows of latewood cells within the earlywood are plotted. It is obvious that the majority of missing rings occurs in years with drastic growth depressions, like in 1914, 1930 or 1982 (compare Fig. 7b). In some cases, like in 1913 and 1981, the formation of light rings can be observed in the year prior to the absent ring, indicating that the causing factor for the growth depression had taken place in the year before.

Figure $7 \mathrm{c}$ shows the occurrence of intra-annual bands and their position within the growth ring. Because of the decreasing sample depth towards the older parts of the chronology, the amount of intra-annual bands is given in percent of the total sample size in each year. Only a small number of intra-annual bands occurs in the latewood part of the tree rings, always synchronously with bands located in the transition zone between earlywood and latewood, the latter representing the majority of intra-annual 

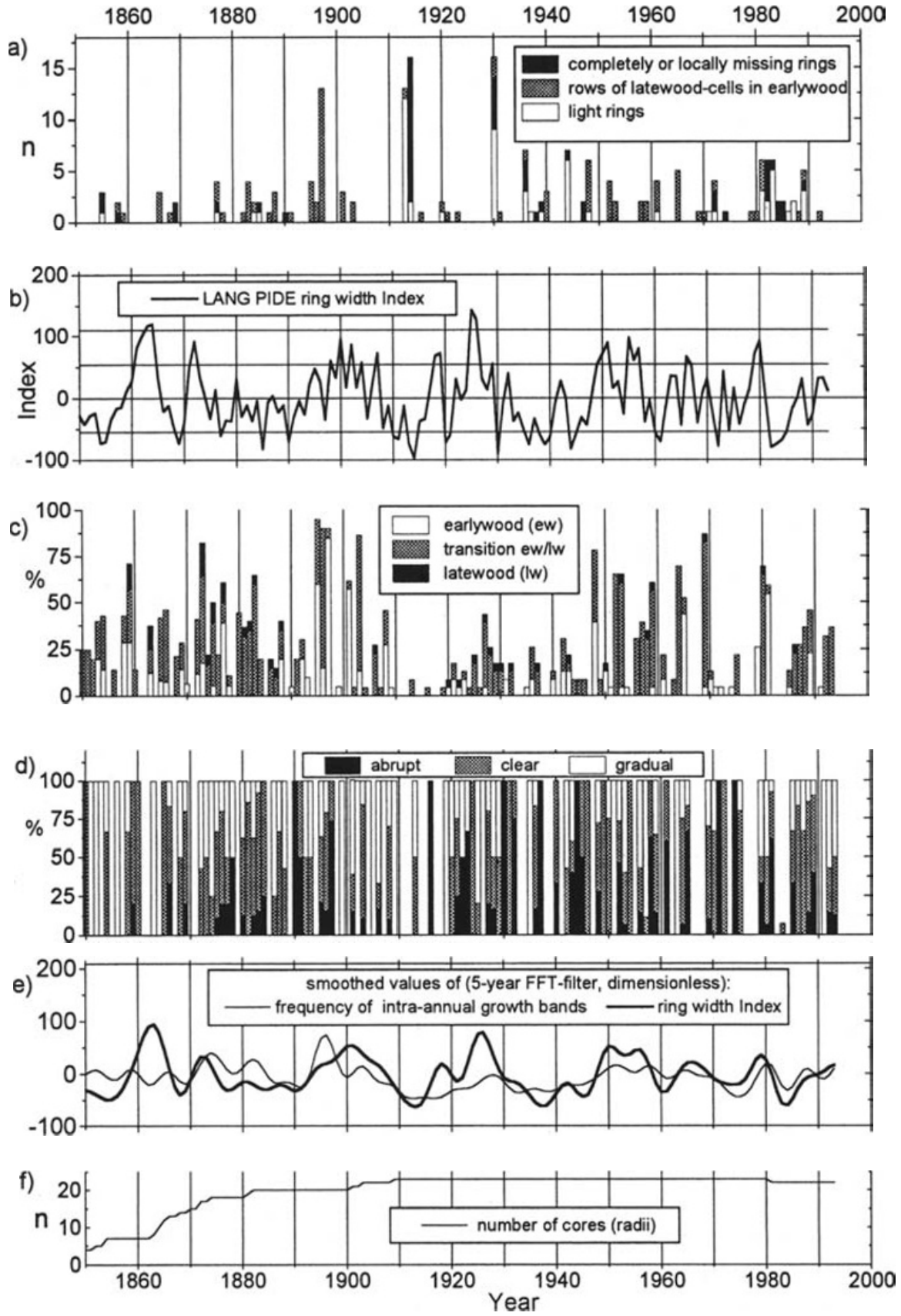

Fig. 7. Record of intra-annual growth bands at the site LANG PIDE for the period 1850-1993; a) occurrence of light rings and totally or partly missing rings; b) ring-width index chronology of LANG.PIDE; c) frequency of intra-annual growth bands and their position within the annual growth rings; d) anatomical character of the transition between cells of different wood anatomy; e) comparison of the smoothed curves of the ring-width index and frequency of intra-annual growth bands; f) sample depth. 
bands observed. In some years, a high amount of intra-annual bands is formed in the earlywood mainly $(1895,1897,1901,1948,1965,1981$ in Fig. 7c), then often in the shape of single rows of latewood-type cells with an abrupt transition to the preceding earlywood (compare Fig. 7a, c \& d).

The discontinuous distribution and the synchronous occurrence of intra-annual growth bands in several trees is a clear indication that the reason for their formation must be seen in unfavorable climatic conditions during the early part of the vegetation period. In this case, the trees start to produce latewood cells with reduced size and thicker cell walls (Villalba \& Veblen 1996). After the return of favorable conditions, cells of the earlywood-type of larger size and with thin cell walls are formed again, until at the end of the growing season latewood cells are produced.

If the growth band is located in the transition zone between earlywood and latewood, the causing climatic event is expected to have occurred during the period of normal earlywood formation, probably during May to June, whereas in years showing density fluctuations in the latewood of many samples, the triggering event is supposed to have happened shortly before the formation of latewood usually starts, probably in July. As the synchronous occurrence of growth bands in different positions of the tree ring $(1859,1863,1873,1875,1927,1953,1959,1969)$ and the highly variable amount of intra-annual bands in different trees show, the formation of a growth band is controlled by the individual water status of a tree, influenced by microsite conditions.

Figure 7e suggests a relationship between ring width and the frequency of intraannual growth layers: The smoothed curve of the growth band frequency shows similar fluctuations as the ring-width chronology, but lagging one year behind. Indeed, a comparison of Figures $7 \mathrm{~b} \& \mathrm{c}$ indicates that intra-annual bands do rarely occur in extremely narrow rings $(1869,1885,1890,1920,1930,1944,1972)$ or during periods of suppressed growth (1910-1920, 1934-1940, 1982-1985). In years with unfavorable growing conditions, the small number of cell rows formed in a narrow ring does not permit the temporal resolution to detect short climatic events occurring during the season of growth, in contrast to years with broad rings, where many layers of earlywood tracheids are formed (Schweingruber 1980).

Intra-annual bands can be found in phases of increasing growth (1858-1863, 1872$1873,1895-1903)$ as well as in phases of decreasing ring width (1864-1870, 1873$1877,1927-1930,1952-1960$ ). While periods of suppressed growth are always connected with a low frequency of intra-annual bands, phases of favorable growing conditions are not necessarily combined with enhanced formation of density fluctuations (1860-1863, 1922-1926). Therefore, growth bands contain information, additional to that in ring widths, about climatic events during the growing season in periods, when the general conditions for the trees are not extremely harsh.

\section{Ecological interpretation of intra-annual growth bands}

To examine the climatological factors relevant for the formation of intra-annual growth bands, the climate data of the station Tsetang (Table 2) were calculated as deviations from the long-term mean and averaged for years with intense formation of growth bands which were selected from Figure $7 \mathrm{c}$. 

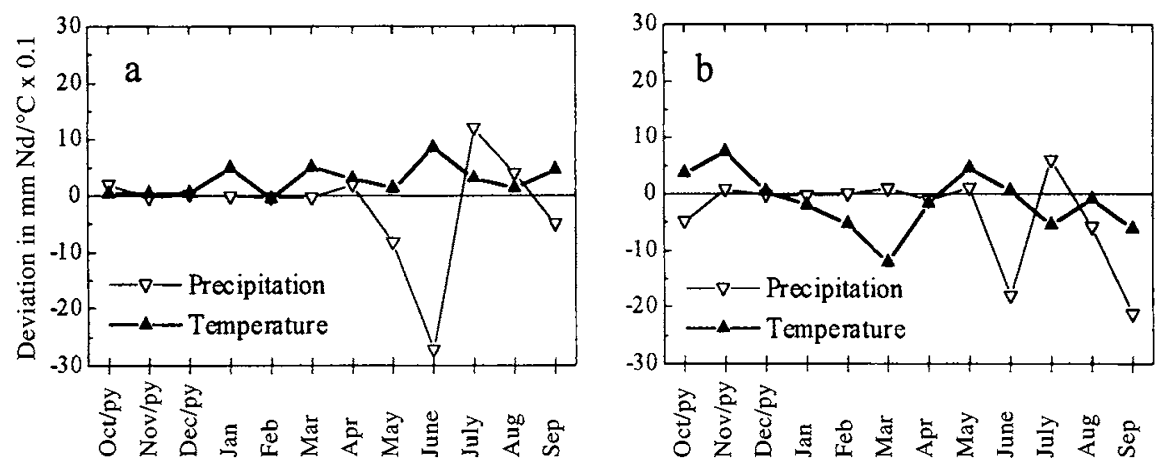

Fig. 8. Climatological situation in years of formation of intra-annual growth bands expressed as averaged deviations of monthly values of temperature and precipitation from October of the previous year (Oct/py.) to September (Sep); a) for years with a growth band in the transition zone between earlywood and latewood (mean of the years 1958, 1959, 1964, 1969, 1985-1989, 1992); b) for years with a growth band within the earlywood (mean of the years $1965,1979,1981$ ).

Figure 8a depicts the climatic situation in years, when the position of the growth band is located mainly in the transition zone between earlywood and latewood. A strong negative anomaly can be seen in the precipitation data of early summer, in May and especially in June, with higher temperatures in June, indicating reduced cloudiness and higher insolation. Since the amount of soil water storage from melted snow must be assumed to be very small due to the dry winter conditions, this situation causes drought stress to the trees, which react with a premature formation of latewood. The climate data then show above-average precipitation in July (Fig. 8a), so that the moisture status of the trees can recover and earlywood-type cells are formed again, before latewood is produced, probably in August. The connection between drought stress and the formation of latewood-type cells is well known from dry forest habitats of different regions (Trendlenburg \& Mayer-Wegelin 1955; Glock 1955; Villalba \& Veblen 1996; Fritts 1976). In southern Tibet, this meteorological situation can be interpreted as a delayed arrival of the moist air masses of the summer monsoon with lowered precipitation in May and June and enhanced rainfall in July.

However, exceptions do exist from this general pattern: In 1980, intra-annual bands are connected with unusually cold $\left(2.1^{\circ} \mathrm{C}\right.$ below average) and moist $(61 \mathrm{~mm}$ precipitation instead of $24 \mathrm{~mm}$ on the average) conditions in May, which might have influenced cambial activity even at this dry site. For a sound explanation of such events, a higher temporal resolution of the climate data is required.

In Figure 8b, the climatic situation of years with growth band-formation in the earlywood is shown. Besides below-average precipitation in June, low temperatures in March do occur. According to our own observations, tree-ring formation at subalpine sites does not start before May or even June. Unfortunately, there are no data available about the seasonality of cambium activity at dry sites far below the alpine tree limit like that of LANG PIDE. Even if it seems to be at a very early point, it cannot be excluded at the moment, that cold conditions in March already might have an influence on tree growth in this location. 


\section{DISCUSSION}

Tree growth at dry sites in southern Tibet can be regarded as a sensitive indicator for climatic fluctuations and can be used as proxy record for the reconstruction of climatic events for the following reasons: ring width is highly correlated with moisture conditions in the late summer prior to the growing season. Probably the carbon storage, which is used to produce the major portion of the earlywood of the next year, is assimilated during that period. Regardless of the tree species, chronologies in the region under consideration show a high degree of similarity and thus a strong common climatic signal.

The occurrence of intra-annual growth bands is restricted to tree stands under very harsh environments, their frequency in a given year can be seen as an indicator of the strength of the triggering event, while the abruptness of the transition between the anatomical cell types can be related to the intensity of the climatic conditions (Villalba \& Veblen 1996). Trees of Pinus densata do not show disturbances in the anatomical ring structure at the site MAIN PIDE only about $60 \mathrm{~km}$ to the east of LANG PIDE, despite their location in the dry valley bottom. Therefore, the formation of intra-annual growth bands, combined with increasing values of statistical parameters like variance and mean sensitivity (Bräuning 1999b), can also be regarded as an indicator of the proximity of the climatic distribution limit. This is of special interest to mark the western border of forest growth in Tibet, since there are strong indications that the currently existing forests are only remnants of their former distribution. The forested area probably drastically diminished since prehistoric times as a consequence of grazing pressure in relation to lifestock keeping by Tibetan heardsmen, construction of buildings, use for fuelwood and the impact of forest fires (Frenzel 1994, 1998; Winkler 1997).

Analyses of the microscopic wood structure can help to determine the climatic potential for tree growth of a region that is currently bare of woodland with the exception of isolated tree stands in sheltered places around monasteries.

For the present study, only monthly means of temperature and precipitation were available. This means a severe constraint for detecting the climatic conditions causing the formation of intra-annual bands, since dry periods with a duration of several weeks might not be represented in the meteorological records. Nevertheless, the vast majority of the observed intra-annual growth bands can be explained by dry conditions in early summer (May, June) and can be attributed to a late arrival time of the summer monsoon in southern Tibet. These growth bands only occur when tree growth is vigorous enough to ensure the required temporal resolution with a sufficient number of cell rows, implying favorable or at least not very unfavorable growing conditions in the previous summer and therefore bringing additional climatological information to total ring width. The combination of both parameters can provide a basis for the reconstruction of rainfall variability and synoptical weather conditions relevant for the history of the monsoon circulation over southeast Asia. 


\section{ACKNOWLEDGEMENTS}

The author is greatly endebted to Prof. Dr. B. Frenzel and Prof. Dr. G. Miehe for the opportunities to take part in their expeditions in 1992,1994, and 1996. For their help in the field I gratefully thank Dipl. Biol. U. Wündisch and A. Schriever, for giving me the material of the site NAM PCLI I thank Dr. M. Groß. The fieldwork has been supported by the Deutsche Forschungsgemeinschaft, the MaxPlanck-Gesellschaft, and the A.F.W. Schimper-Stiftung.

\section{REFERENCES}

Anonymous. 1990. Atlas of the Tibetan Plateau. Institute of Geography, Academia Sinica, Beijing (ed.), Science Press Beijing (in Chinese). 235 pp.

Böhner, J. 1994. Circulation and representativeness of precipitation and air temperature in the southeast of the Qinghai-Xizang plateau. GeoJournal 34: 55-66.

Böhner, J. 1996. Säkulare Klimaschwankungen und rezente Klimatrends Zentral- und Hochasiens. Gött. Geogr. Abh. 101. 166 pp.

Bradley, R.S. \& P.D. Jones. 1992. Climate since A.D. 1500: Introduction. In: R. S. Bradley \& P.D. Jones (eds.), Climate since A.D. 1500: 1-16. Routledge, London.

Bräker, O.U. 1981. Der Alterstrend bei Jahrringdichten und Jahrringbreiten von Nadelhölzern und sein Ausgleich. Mittlg. der Forstl. Bundesversuchsanstalt Wien 142: 75-102.

Bräuning, A. 1994. Dendrochronology for the last 1400 years in Eastern Tibet. GeoJournal 34: 75-95.

Bräuning, A. 1999a (in print). Ecological division of forest regions of eastern Tibet by use of dendroecological analyses. Marburger Geographische Schriften.

Bräuning, A. 1999b. Zur Dendroklimatologie Hochtibets während des letzten Jahrtausends. Dissertationes Botanicae 312, 164 pp. Univ. Hohenheim.

Chang. 1981. The vegetation zonation of the Tibetan plateau. Mountain Res. and Dev. 1, 1: $29-48$.

Cook, E.R., K.R. Briffa, D.M. Meko, D.A. Graybill \& G. Funkhouser. 1995. The 'segment length curse' in long tree-ring chronology development for palaeoclimatic studies. Holocene 5: 229-237.

Domrös, M. \& Peng Gongbing. 1988. The climate of China. Springer Verlag Berlin. 361 pp.

Flohn, H. 1958. Beiträge zur Klimakunde von Hochasien. Erdkunde 12: 294-308.

Flohn, H. 1987. Recent investigations on the climatogenetic role of the Qinghai-Xizang Plateau: Now and during the late Cenozoic. In: J. Hövermann \& Wang Wenying (eds.), Reports on the northeastern part of the Qinghai-Xizang (Tibet) Plateau: 387-416. Science Press, Beijing.

Frenzel, B. 1994. Über Probleme der holozänen Vegetationsgeschichte Osttibets. Gött. Geogr. Abh. 95: 143-165.

Frenzel, B. 1998. History of flora and vegetation during the Quaternary. Progress in Botany 59: 599--633.

Fritts, H.C. 1976. Tree rings and climate. Academic Press, London. 567 pp.

Glock, W. 1955. Tree growth. II. Growth rings and climate. Bot. Rev. 21: 73-188.

Grissino-Mayer, H.D. 1993. An updated list of species used in tree-ring research. Tree-Ring Bull. 53: 17-43.

Haffner, W. 1997. Hochasien: Der Effekt großer Massenerhebungen. Geogr. Rundsch. 5: 307314.

Krauter, U. 1997. Dendrochronologische Untersuchungen zu Brandereignissen in osttibetischen Wäldern und deren Einfluß auf die Waldverteilung. Zulassungsarbeit, Univ. Stuttgart, 67 pp., unpubl. 
Li Bosheng. 1993. The alpine timberline of Tibet. In: J. Alden, J.L. Mastrantonio \& S. Odum (eds.), Forest development in cold climates, NYC: 511-527.

Murakami, T. 1987. Effects of the Tibetan Plateau. In: C.-P. Chang \& T.N. Krishnamurti, (eds.), Monsoon meteorology. Oxford Monographs on Geology and Geophysics 7: 235270.

Schweinfurth, U. 1956. Über klimatische Trockentäler im Himalaya. Erdkunde 10: 297-302.

Schweinfurth, U. 1957. Die horizontale und vertikale Verbreitung der Vegetation im Himalaya. Bonner Geogr. Abh. 20. 375 pp.

Schweinfurth, U. 1981. Plateau, river gorges, and local wind phenomena. Geological and ecological studies of Qinghai-Xizang Plateau. Proc. Symp. on Qinghai-Xizang (Tibet) Plateau, Vol. II, Beijing: 2005-2010.

Schweingruber, F.H. 1980. Dichteschwankungen in Jahrringen von Nadelhölzern in Beziehung zu klimatisch-ökologischen Faktoren, oder das Problem der falschen Jahrringe. Eidg. Anst. forstl. Versuchswesen, Berichte 213. 35 pp.

Trendelenburg, R. \& H. Mayer-Wegelin. 1955. Das Holz als Rohstoff. Hanser Verl. München. 541 pp.

Villalba, R. \& T.T. Veblen.1996. A tree-ring record of dry spring - wet summer events in the forest-steppe ecotone, northern Patagonia, Argentina. In: J.S. Dean, D.M. Meko \& T.W. Swetnam (eds.), Tree rings, environment and humanity. Radiocarbon: 107-116.

Winkler, D. 1997. Waldvegetation in der Ostabdachung des tibetischen Hochlands und die historische und gegenwärtige Entwaldung. Erdkunde 51: 143-164. 